УДК 341.24:502

DOI: 10.30914/2227-6874-2019-12-94-103

\title{
Ensuring the safety of transboundary water resources: European experience
}

\author{
L. V. Boronina, B. Lhagvadulam,
} E. V. Davydova, G. Werner, A. F. Sokolsky

Ensuring the safety of transboundary water resources has been assigned by the Russian government to national priorities. The foundation of cross-border cooperation is the process of creating and implementing contractual relations in the border areas, which are aimed at finding solutions to the tasks. International experience suggests that cross-border interaction is the main factor in expanding interethnic economic ties, and the rational use of the advantages of cross-border location provides an opportunity to give a strong impetus to the development of territories. Water resources often cause international tensions and conflicts over access to and use of them. Therefore, one of the most important transboundary tasks is the safe supply of water, the need to ensure rational use, equitable distribution and provision of water for those who need it. A striking example of a transboundary reservoir is the Caspian Sea, according to which on August 12, 2018, the Convention on the Regulation of the Rights and Obligations of States located on the Caspian Sea Coast was signed in Kazakhstan, taking into account the environmental factor in the implementation of large-scale offshore projects. The article provides an analysis of the best European experience in managing transboundary water bodies, proposes measures that will make it possible to improve the economic and environmental factor of managing the Caspian Sea. The implementation of the provisions of the Convention by the Caspian littoral states will promote good neighborliness and mutually beneficial cooperation based on European experience, promote the peaceful use of the Caspian Sea, the rational use of its resources, the study, protection and preservation of its natural environment. The results of scientific monitoring studies on marine pollution in the shallow zone of the western part of the Caspian are presented, conclusions are drawn about the need to continue research and disseminate information.

Keywords: transboundary water body, marine environment, water resources management, international cooperation, ecology, European experience, environmental safety.

Citation for an article: Boronina L.V., Lhagvadulam B., Davydova E.V., Werner G., Sokolsky A.F. Ensuring the safety of transboundary water resources: European experience. West - East. 2019, no. 12, pp. 94-103. DOI: 10.30914/ 2227-6874-2019-12-94-103

() Боронина Л. В., Лхагвадулам Б., Давыдова Е. В., Вернер Г., Сокольский А. Ф., 2019 
There are 263 transboundary river basins in the world, with approximately two thirds of them lacking a joint management program. International waters require international standards: EU promotes international water cooperation agreements and welcomes the opening of the Convention on Transboundary Waters for countries outside the pan-European region.

The most extensive development of the safety of transboundary water bodies was in Western Europe. It was from Europe that the evolutionary process of forming the regulatory framework for cross-border interaction began. In the regulatory documents of the Council of Europe since the 1970s "cross-border regionalization" and the development of "inter-regional cross-border cooperation" were identified among the priorities of the European regional policy. The main legal document governing the process was the European Framework Convention on Cross-Border Cooperation between Territorial Communities and Authorities (Madrid Convention) 1980. Supported by two protocols (adopted on November 9, 1995 and May 5, 1998, respectively), the Convention secured the obligations of the signatories to maintain and facilitate cross-border cooperation between territorial communities and authorities under their jurisdiction.

Recent scientific literature on international cooperation in the field of water resources management pays special attention to these issues in those regions of the world where water scarcity may or may already be one of the most important factors in the emergence of international conflicts. Effective water management thus becomes a matter of war and peace in these regions.

In 1992, under the auspices of the United Nations Economic Commission for Europe, the Convention on the Protection and Use of Transboundary Watercourses and International Lakes, better known among experts as the Helsinki Convention, was signed [1]. She determined the legal status of transboundary water bodies in Europe, where state borders are drawn along more than 150 large rivers and more than 50 large lakes. The Helsinki Convention is equally important for Southern Europe, primarily because of the Danube factor, and for the Baltic region. In the Baltic region, such rivers as the Vistula, Vuoksa, Zapadnaya Dvina, Mamonovka, Narva, Neman, Oder, Tourne-Elv and Sventoji, as well as over a dozen smaller rivers flow through two, and sometimes more, states. Here is Lake Peipsi - the largest lake in Estonia, along which passes part of the state border between Estonia and Russia.

However, transboundary water resources are not exclusively a European phenomenon. Some water resources are located partly on the territory of European countries, and partly on the territory of the Middle East or Asia. Awareness of the significance of this problem led to the adoption in 2003 of amendments to the Helsinki Convention, according to which now not only European countries can become its participants.

The Caspian Sea is the largest lake on Earth, drainless, located at the junction of Europe and Asia. The states located on the coast of the Caspian Sea are the Republic 
of Azerbaijan, the Islamic Republic of Iran, the Republic of Kazakhstan, the Russian Federation and Turkmenistan.

For a long time, the legal regime of the Caspian was established by the SovietIranian treaties of 1921 and 1940. These agreements provided for freedom of navigation throughout the sea, freedom of fishing with the exception of ten-mile national fishing zones and a ban on vessels flying the flag of non-Caspian states in its water area and did not contain points for the protection and rational use of water resources.

The littoral states are convinced that the Caspian Sea has vital political, economic, social and cultural significance. Therefore, recognizing their responsibility to present and future generations for the preservation of the Caspian Sea, the sustainable development of the region, striving to create favorable conditions for the development of mutually beneficial economic cooperation in the Caspian Sea, taking into account the changes and processes taking place in the Caspian Sea region at the geopolitical and national levels, the Caspian states have reached agreements on the need to improve the legal regime of the Caspian Sea.

On August 12, 2018, Kazakhstan signed the Convention on the Regulation of the Rights and Obligations of States located on the Caspian Sea, taking into account the environmental factor in the implementation of large-scale offshore projects. The implementation of the provisions of the Convention by the Caspian littoral states will promote good neighborliness and mutually beneficial cooperation based on European experience, promote the peaceful use of the Caspian Sea, the rational use of its resources, the study, protection and preservation of its natural environment.

This Convention defines and governs the rights and obligations of States Parties with respect to the use of the Caspian Sea, including its waters, bottom, subsoil, natural resources and airspace above the sea.

Opportunities for solving environmental problems are closely related to the availability of environmental information. Full, reliable and timely information about the state of the environment and the levels of anthropogenic impact on it should be open and accessible to all citizens and should not be a state or other secret.

In particular, one of the articles of the Convention indicates that when conducting marine scientific research, the Party that conducts marine scientific research shall ensure to the Party that authorized the conduct of marine scientific research the right to participate or be represented in such research, especially on-board research vessels when it is practically possible. The Party conducting marine scientific research in accordance with paragraphs 1,2 of these articles shall provide the Party that authorized the conduct of such research, the results and conclusions after the completion of the marine scientific research, as well as access to all data and samples obtained in the framework of such research.

Obligations to ensure the environmental safety of the Caspian Sea are contained in Article 15 of the Convention. According to the agreements, the Parties 
undertake to protect and preserve the ecological system of the Caspian Sea and all its components.

The Caspian littoral states independently or jointly take all necessary measures and cooperate in order to preserve biological diversity, protect, restore, sustainable and rational use of biological resources of the Caspian Sea, prevent, reduce and control pollution of the Caspian Sea from any source.

They are prohibited from activities that damage the biological diversity of the Caspian Sea and, in accordance with international law, the Caspian states are liable for damage to the ecological system of the Caspian Sea.

Currently, scientific monitoring studies on the state of pollution of the Caspian Sea are being carried out in the Russian Federation. Within the framework of the state contract GK 16.552.11.7051 dated 07.29.2011, 16.740.11.0051 dated 01.09.2010, studies were carried out on the state of pollution of the Northern Caspian, confirming the need for regular joint work.

In surface waters in the western part of the North Caspian in 2005-2007 total nitrogen concentrations ranged from 568 to $1321 \mu \mathrm{g} / \mathrm{L}$, with an average value of $856 \mu \mathrm{g} / \mathrm{L}$, in bottom waters - from 534 to $1418 \mu \mathrm{g} / \mathrm{L}$, the average $-866 \mu \mathrm{g} / \mathrm{L}$. The maximum values in the surface and bottom layers were recorded in the central part of the studied area - up to 1321 and $1418 \mu \mathrm{g} / \mathrm{l}$, respectively, the minimum in the surface and bottom waters of the eastern part of the area - up to 568 and $534 \mu \mathrm{g} / \mathrm{l}$. Organic nitrogen concentrations varied on the surface from 497 to $1290 \mu \mathrm{g} / \mathrm{L}$, with an average value of $807 \mu \mathrm{g} / \mathrm{L}$, at the bottom - from 456 to $1335 \mu \mathrm{g} / \mathrm{L}$, with an average value of $813 \mu \mathrm{g} / \mathrm{L}$. On the surface and in the bottom layers, the maximum was recorded in the central part of the water area 1290 and $1335 \mu \mathrm{g} / \mathrm{l}$, respectively, the minimum - in the east of the studied water area -497 and $456 \mu \mathrm{g} / \mathrm{l}$, respectively. The concentrations of ammonia nitrogen in surface waters varied from 14 to $54 \mu \mathrm{g} / \mathrm{L}$ (average $-28 \mu \mathrm{g} / \mathrm{L}$ ), in bottom waters, respectively, from 14 to $57 \mu \mathrm{g} / \mathrm{L}$, with an average value of $33 \mu \mathrm{g} / \mathrm{L}$. The maximum concentrations of ammonia nitrogen in the surface Vedas were recorded in the eastern part of the water area - up to $54 \mu \mathrm{g} / \mathrm{l}$, in the bottom - also in the eastern part - up to $57 \mu \mathrm{g} / \mathrm{l}$. There were no excess MPC values $(500 \mu \mathrm{g} / \mathrm{L})$ in the surface and bottom waters of the studied water area.

The water content of nitrite nitrogen in the surface layer over most of the water area was below the detection limit of the analysis method used (less than $5 \mu \mathrm{g} / \mathrm{l})$. At five points in surface waters, nitrite nitrogen concentrations of up to $11 \mu \mathrm{g} / \mathrm{L}$ were recorded. In bottom waters in the water area, only in three samples were nitrite nitrogen concentrations higher than the detection limit - up to $37 \mu \mathrm{g} / \mathrm{l}$.

Concentrations of nitrate nitrogen in surface waters in the surveyed water area varied from 3 to $57 \mu \mathrm{g} / \mathrm{L}$ (average $-16 \mu \mathrm{g} / \mathrm{L}$ ), in bottom waters, respectively, from 4 to $57 \mu \mathrm{g} / \mathrm{L}$, with an average value of $15 \mu \mathrm{g} / \mathrm{L}$. The maximum concentrations of nitrate nitrogen in the surface and bottom layers were recorded in the western 
part of the water area - up to $57 \mu \mathrm{g} / \mathrm{L}$, the minimum - in surface and bottom waters of its central part - up to 3 and $4 \mu \mathrm{g} / \mathrm{L}$, respectively. There were no excess MPC values $(40 \mathrm{mg} / \mathrm{l})$ in surface and bottom waters.

In autumn, the concentration of total nitrogen in surface waters in the surveyed water area varied from 416 to $1252 \mu \mathrm{g} / \mathrm{L}$ with an average value of $837 \mu \mathrm{g} / \mathrm{L}$, in bottom waters - from 415 to $1227 \mu \mathrm{g} / \mathrm{L}$, the average $-826 \mu \mathrm{g} / \mathrm{L}$. The maximum concentrations in the surface and in the bottom, layers were recorded in the western part of the studied area - up to 1252 at $1227 \mu \mathrm{g} / \mathrm{l}$, respectively, the minimum - in surface and bottom waters of the central part of the water up to 416 and $415 \mu \mathrm{g} / 1$, respectively.

The concentration of organic nitrogen varied on the surface from 395 to $1189 \mathrm{mg} / \mathrm{L}$ with an average value of $797 \mu \mathrm{g} / \mathrm{L}$, at the bottom - from 394 to $1170 \mu \mathrm{g} / \mathrm{L}$ with an average value of $794 \mu \mathrm{g} / \mathrm{L}$. On the surface and in the bottom layer, the maximum was recorded in the western part of the water area -1189 and $1198 \mu \mathrm{g} / \mathrm{l}$, respectively, the minimum - in the central part of the water area 395 and $394 \mu \mathrm{g} / 1$, respectively.

The concentration of ammonia nitrogen in surface waters in the water area of the licensed area varied from 6.9 to $147.6 \mu \mathrm{g} / \mathrm{L}$ (average $-17.2 \mu \mathrm{g} / \mathrm{L}$ ). The concentration of ammonia nitrogen in bottom waters in the studied water area varied from 6.7 to $39.5 \mathrm{mg} / \mathrm{l}$ with an average value of $18.3 \mu \mathrm{g} / \mathrm{l}$. The maximum concentrations of ammonia nitrogen in surface waters were recorded in the western part of the study area - up to $148 \mu \mathrm{g} / \mathrm{l}$. There were no excesses of the maximum permissible concentration of ammonium nitrogen $(500 \mu \mathrm{g} / \mathrm{l})$ in the surface and bottom waters of the studied water area. The concentration of nitrite nitrogen in surface and bottom waters throughout the water area of the structure was below the detection limit of the analysis method used (less than $5 \mu \mathrm{g} / \mathrm{l}$ ).

The concentration of nitrate nitrogen in surface waters in the surveyed water area varied from 12.7 to $115.5 \mu \mathrm{g} / \mathrm{L}$ (average $-22.6 \mathrm{mg} / \mathrm{L}$ ), in the bottom from 13.2 to $35.4 \mathrm{mg} / \mathrm{L}$ with an average of $18.3 \mathrm{mcg} / \mathrm{l}$. The maximum concentrations of nitrate nitrogen on the surface were recorded in the western part of the water area $-115.5 \mu \mathrm{g} / \mathrm{l}$, in the bottom layer - in the central part of the water area $-35.4 \mu \mathrm{g} / 1$, the minimum - in the surface and bottom waters of its eastern part - up to 12,7 and $13.2 \mathrm{mcg} / 1$, respectively.

The average concentration of petroleum hydrocarbons in water, as a rule, was in the range from 0.05 to $0.10 \mathrm{mg} / \mathrm{L}$. The only exception was the increased concentration of petroleum hydrocarbons recorded in the summer of 2005, amounting to $0.11 \mathrm{mg} / \mathrm{l}$ and the reduced concentration of petroleum hydrocarbons observed in the same year, but already in autumn, equal to $0.03 \mathrm{mg} / \mathrm{l}$. In subsequent years, the content of petroleum hydrocarbons in water increased from summer to autumn.

Interannual changes in the concentration of phenols in water were similar to changes in the concentration of petroleum hydrocarbons. From the above data, 
it follows that the average concentration of phenols, as a rule, was in the range from $0.002 \mathrm{mg} / 1$ (1-2 MPC).

The average concentration of surfactants during the observation period decreased from $0.20-0.30 \mathrm{mg} / \mathrm{L}$ to $0.03-0.04 \mathrm{mg} / \mathrm{L}$. It is interesting that every year against this background, an increase in the content of surfactants in water from summer to autumn was observed.

Iron in the period under consideration was characterized by a steady increase in concentration in water in the summer season. In 2005-2006 an increase in concentration from summer to autumn was also noted.

During the study period, the average concentration of zinc in water gradually decreased from $30-45 \mu \mathrm{g} / \mathrm{L}$ to $10-13 \mu \mathrm{g} / \mathrm{L}$. In this case, as a rule, the concentration of zinc in water from summer to autumn also decreased.

The average concentration of manganese in water in the summer season for all three years remained unchanged. In 2005-2006 the concentration of manganese in the autumn season, which during these years was lower than in the summer, remained virtually unchanged. These features in the dynamics of manganese in water were violated in the fall of 2007, when the highest average concentration of manganese in water was recorded.

In connection with the identified contaminants, it was important to evaluate the mutagenicity of the environment and its effect on fish. It turned out that the frequency of chromosomal aberrations in the studied area averaged $3.3 \%$. The average mitotic index was $5.0 \%$. The range of fluctuations in the frequency of occurrence of pathological mitoses was low. The symptom ranged from 2.9 to $4.5 \%$. The limits of the mitotic index were 4.2-5.9. These effects occurred in the epithelium of the fin border of fish under the influence of the tested bottom sediments. In $45 \%$ of soil samples, the yield of chromosomal abnormalities was within the range acceptable for spontaneous aberrations. The presence of about $55 \%$ of soil samples in excess of the recognized normal level indicates the presence of xenobiotics in the bottom sediments of the North Caspian with a genotoxic effect. This indicator is increased compared to 2003 and corresponds to 2001 values. Nevertheless, judging by the average incidence of abnormal mitoses, which, in general, in structure has remained practically unchanged for several years, the studied region remains sufficiently well received.

In this water area, a low level of exceeding the permissible values of chromosomal aberrations is noted. Most of the obtained values (74 \% of samples) of this trait lie in the range of 2.9-3.5\%. Nevertheless, we can speak of the presence of weak genotoxic effects.

Of the structural defects in the chromosomes, mainly single and paired bridges, fragments and lagging chromosomes were found.

Explicit seasonal dynamics, probably due to the close terms of summer and autumn filming, are not observed. However, it should be noted a slight decrease 
in proliferative activity and the proportion of aberrant mitoses in the autumn period (5.1 \% and $3.4 \%$, respectively) compared with the summer period ( $4.8 \%$ and $3.2 \%$, respectively). The highest values of the characteristic are noted at stations 16,15 , then, in decreasing order, at stations $4-2,8,9,12$ both in summer and in autumn. As you can see, cytogenetic effects were localized mainly in the southeastern part of the polygon. Apparently in this area there is a sedimentation of substances carried into the sea by the Volga and partly by the Urals. This determines the ongoing physicochemical and biological processes. In addition, it should be noted that shell-and-sand fractions of bottom sediments prevail in this area and the absence of silty soil, which contains organic matter, which, depending on the composition, can significantly reduce the toxicity of xenobiotics.

The mitotic index did not go beyond $5.7 \%$, which is close to traditional values and indicates the absence of a carcinogenic effect.

Thus, at present, the environmental situation in the northwestern shallow part of the North Caspian can be called satisfactory.

Thus, the studies on the state of pollution of the Northern Caspian confirm the need for regular joint scientific work to improve and preserve the marine environment and environmental education of the population of the Caspian states.

\section{References}

1. Arskiy Yu.M., Chernyi A.I. Informatsionnye resursy dlya ustoichivogo razvitiya obshchestva [Information resources for sustainable development of society]. Mezhdunar. forum po informatsii $=$ Int. information forum, 2003, vol. 28, no. 4, pp. 3-9. (In Russ.).

2. Bychkova E.F. Vidy ekologicheskoi informatsii i sposoby ee predostavleniya [Types of environmental information and methods for its provision]. Nauchnye i tekhnicheskie biblioteki: ezhemes. nauchnopraktich. zhurnal dlya spetsialistov bibliotechno-informatsionnoi $i$ smezhnykh otraslei $=$ Scientific and technical libraries: monthly scientific and practical magazine for specialists of library and information and related industries, GPNTB Rossii, 2008, no. 4, p. 83-89. Available at: http:/intranet.gpntb.ru/ subscribe/index.php?journal=ntb\&year $=2008 \&$ num $=4 \& a r t=9$ (accessed 5.10.2019). (In Russ.).

3. Dubovik O.L. Pravo dostupa k informatsii o sostoyanii okruzhayushchei sredy [The right to access environmental information]. Na puti $k$ ustoichivomu razvitiyu Rossii $=$ On a way to sustainable development of Russia, 2001, issue 6 (17), pp. 35-36. (In Russ.).

4. Evtushenko V.I. Sovremennye problemy realizatsii konstitutsionnogo prava grazhdan na blagopriyatnuyu okruzhayushchuyu sredu (ekologicheskikh prav cheloveka) [Modern problems of the implementation of the constitutional right of citizens to a favorable environment (environmental human rights)]. Ekologicheskie issledovaniya $=$ Environmental studies, 2016, no. 1, pp. 19-24. DOI: 10.7256/2453-8833.2016.1.20084 (In Russ.).

5. Elizarov A., Smelyanskiy I. Ekologicheskaya informatsiya v Rossii: obzorno-spravoch. izd. [Environmental Information in Russia: a reference publication]. Samara, Laboratoriya prirodnykh ekosistem IEKA «Povolzh'e», 1998, 208 p. (In Russ.).

6. Malkova M.A., Vozhdaeva M.Yu., Kantor E.A. Otsenka kantserogennogo riska zdorov'yu naseleniya, svyazannogo s kachestvom pit'evoi vody vodozaborov poverkhnostnogo i infil'tratsionnogo tipov [Assessment of carcinogenic risk to population health due to the quality of drinking water of surface and infiltration water intakes]. Voda $i$ ekologiya: problemy $i$ resheniya $=$ Water and Ecology, 2018, no. 1 (73), pp. 59-64. DOI: 10.23968/2305-3488.2018.23.1.59-64 (In Russ.). 
7. Ol'kova A.S. Aktual'nye napravleniya razvitiya metodologii biotestirovaniya vodnykh sred [Current trends in the development of the methodology of bioassay aquatic environments]. Voda $i$ ekologiya: problemy $i$ resheniya $=$ Water and Ecology, 2018, no. 2 (74), pp. 40-50. DOI: 10.23968/2305-3488.2018.20.2.40-50 (In Russ.).

8. Suleimenova S.Zh., Askarova A.O. Voprosy pravovogo regulirovaniya ratsional'nogo ispol'zovaniya transgranichnykh rek i vodoemov [Legal regulation of the management of transboundary rivers and reservoirs]. Vestnik YuUrGU. Seriya "Pravo»= Bulletin of the South Ural State University. Ser. Law, 2015, vol. 15, no. 2, pp. 104-109. (In Russ.).

9. Tayia A. Transboundary Water Conflict Resolution Mechanisms: Substitutes or Complements. Water 2019, 11, 1337. DOI: 10.3390/w11071337

10. Zeitoun M., Mirumachi N., Warner J., Kirkegaard M., Cascão A. Analysis for water conflict transformation. Water Int. 2019, 1-20. DOI: 10.1080/02508060.2019.1607479

Submitted 19.10.2019; revised 20.11.2019.

All authors have read and approved the final manuscript.

\section{About the authors}

Lyudmila V. Boronina

$\mathrm{Ph}$. D. (Technical Sciences), Professor, Vice-rector for Science and International Affairs, Astrakhan State University of Architecture and Civil Engineering, Astrakhan, boroninalv@gmail.com

\section{Lkhagvadulam Byambajav}

Senior lecturer, doctor (Ph.D), Enviromental Engineering Department, Mongolian University of Science and Technology, Mongolia, Ulaanbaatar,Lkhagvadulam@must.edy.mn

\section{Ekaterina V. Davydova}

Assistant of the Department of Engineering Systems and Ecology, Astrakhan, Astrakhan State University of Architecture and Civil Engineering katya_11_05@mail.ru

\section{Gornik Werner}

Professor, Doctor Mathematician, Technische Hochschule Köln, Germany, werner.gornik@th-koeln.de

\section{Arkadii F. Sokolsky}

Dr. Sci. (Biology), Professor of the Department of Engineering Systems and Ecology, Russia, Astrakhan, Astrakhan State University of Architecture and Civil Engineering, Astrakhan, a.sokolsky@mail.ru

\section{Обеспечение безопасности трансграничных водных ресурсов: европейский опыт}

\section{Л. В. Боронина, Б. Лхагвадулам, Е. В. Давыдова, В. Горник, А. Ф. Сокольский}

Обеспечение безопасности трансграничных водных ресурсов отнесено правительством России к общенациональным приоритетам. Фундаментом приграничного сотрудничества выступает процесс создания и реализации договорных отношений на приграничных территориях, которые нацелены на поиск 
решений поставленных задач. Международный опыт говорит о том, что трансграничное взаимодействие выступает основным фактором в расширении межнациональных хозяйственных связей, а рациональное применение преимуществ приграничного расположения предоставляет возможность дать сильный импульс для развития территорий. Водные ресурсы часто становятся причиной международной напряженности и конфликтов, связанных с доступом к ним и их использованием. Поэтому одна из важнейших трансграничных задач - безопасное снабжение водой, необходимость обеспечения рационального использования, справедливого распределения и предоставления воды в распоряжение тем, кто в ней нуждается. Ярким примером трансграничного водоема является Каспийское море, по которому 12 августа 2018 года в Казахстане была подписана Конвенция о регулировании прав и обязанностей государств, расположенных на побережье Каспийского моря, учитывающая экологический фактор при реализации крупномасштабных морских проектов. В статье приводится анализ лучшего европейского опыта управления транграничными водными объектами, предлагаются к реализации мероприятия, которые дадут возможность улучшить экономический и экологический фактор управления Каспийским морем Выполнение положений Конвенции Прикаспийскими государствами будет способствовать добрососедству и взаимовыгодному сотрудничеству, основанному на европейском опыте, содействовать использованию Каспийского моря в мирных целях, рациональному использованию его ресурсов, изучению, защите и сохранению его природной среды. Приведены результаты научных мониторинговых исследований по загрязнениям морской среды в мелководной зоне западной части Каспия, сделаны выводы о необходимости продолжения проведения научных исследований и распространения информации.

Ключевые слова: трансграничные водные ресурсы, морская среда, управление водными ресурсами, международное сотрудничество, экология, Европейский опыт, экологическая безопасность.

Для цитирования: Боронина Л.В., Лхагвадулам Б., Давыдова Е.В., Горник В., Сокольский А.Ф. Обеспечение безопасности трансграничных водных ресурсов: европейский опыт // Запад - Восток. 2019. № 12. С. 94-103. DOI: $10.30914 / 2227-6874-2019-12-94-103$

\section{Список литературы}

1. Арский Ю.М., Черный А.И. Информационные ресурсы для устойчивого развития общества // Междунар. форум по информации. 2003. Т. 28. № 4. С. 3-9.

2. Бычкова Е.Ф. Виды экологической информации и способы ее предоставления // Научные и технические библиотеки: ежемес. научно-практич. журнал для специалистов библиотечно-информационной и смежных отраслей / ГПНТБ России. 2008. № 4. С. 83-89. URL: http://intranet.gpntb.ru/ subscribe/index.php?journal=ntb\&year=2008\&num=4\&art=9 (дата обращения: 5.10.2019).

3. Дубовик О.Л. Право доступа к информации о состоянии окружающей среды // На пути к устойчивому развитию России. 2001. Вып. 6 (17). С. 35-36. 
4. Евтушенко В.И. Современные проблемы реализации конституционного права граждан на благоприятную окружающую среду (экологических прав человека) // Экологические исследования. 2016. № 1. С. 19-24. DOI: 10.7256/2453-8833.2016.1.20084

5. Елизаров А., Смелянский И. Экологическая информация в России: обзорно-справоч. изд. Самара : Лаборатория природных экосистем ИЭКА «Поволжье», 1998. 208 с.

6. Малкова М.А., Вождаева М.Ю., Кантор Е.А. Оценка канцерогенного риска здоровью населения, связанного с качеством питьевой воды водозаборов поверхностного и инфильтрационного типов // Вода и экология: проблемы и решения. 2018. № 1 (73). C. 59-64. DOI: 10.23968/2305-3488.2018.23.1.59-64

7. Олькова А.С. Актуальные направления развития методологии биотестирования водных сред // Вода и экология: проблемы и решения. 2018. № 2 (74). C. 40-50. DOI: 10.23968/23053488.2018.20.2.40-50

8. Сулейменова С.Ж., Аскарова А.О. Вопросы правового регулирования рационального использования трансграничных рек и водоемов // Вестник ЮУрГУ. Серия «Право». 2015. Т. 15. № 2. C. 104-109.

9. Tayia A. Transboundary Water Conflict Resolution Mechanisms: Substitutes or Complements. Water 2019, 11, 1337. DOI: 10.3390/w11071337

10. Zeitoun M., Mirumachi N., Warner J., Kirkegaard M., Cascão A. Analysis for water conflict transformation. Water Int. 2019, 1-20. DOI: 10.1080/02508060.2019.1607479

Статья поступила в редакцию 19.10.2019 г.; принята к публикации 20.11.2019 2. Все авторы прочитали и одобрили окончательный вариант рукописи.

\section{Об авторах}

\section{Боронина Людмила Владимировна}

кандидат технических наук, профессор, проректор по научной работе и международной деятельности, Астраханский государственный архитектурно-строительный университет, г. Астрахань, boroninalv@gmail.com

\section{Лхагвадулам Бямбаджав}

старший преподаватель, доктор философии, инженерно-экологический факультет, Монгольский университет науки и техники, Монголия, Улан-Батор, Lkhagvadulam@must.edy.mn

\section{Давыдова Екатерина Васильевна}

ассистент кафедры инженерных систем и экологии, Россия, Астрахань, Астраханский государственный архитектурно-строительный университет, г. Астрахань, katya_11_05@mail.ru

\section{Горник Вернер}

профессор, доктор математики, Technische Hochschule Köln, (Кельн, Германия), werner.gornik@th-koeln.de

\section{Сокольский Аркадий Федорович}

доктор биологических наук, профессор кафедры инженерных систем и экологии, Астраханский государственный архитектурно-строительный университет, г. Астрахань, a.sokolsky@mail.ru 